\title{
Research on Interest Rate Marketization and Risk Control of Commercial Banks
}

\author{
Tao Liang ${ }^{1, a}$ \\ ${ }^{1}$ Tianjin University, Tianjin, China, 300072 \\ aemail,
}

Keywords: Interest Rate, Marketization, Risk Control, Commercial Banks

\begin{abstract}
After interest rate marketization, interest rate risk control will be an important aspect of risk management of commercial banks in China. This paper analyzes the main risks that Chinese commercial banks will face in the process of interest rate marketization and the current situation of Chinese commercial banks in interest rate risk management. On this basis, the author puts forward the strategy of controlling the interest rate risk of Chinese commercial banks.
\end{abstract}

\section{Introduction}

Interest rate marketization is an important part of improving the degree of financial marketization in China, and its implementation steps are accelerating. The marketization of interest rates gives commercial banks access to capital pricing, and also makes a major market risk - interest rate risk. On the basis of analyzing the risk of marketization of interest rate, this paper points out that the control of interest rate risk requires both the organization and management of commercial banks and the technical proficiency, and the policy transparency and market incentive of financial supervision departments.

\section{The Interest Rate Marketization and the Interest Rate Risk Analysis of Commercial Banks}

Interest rate marketization refers to the government to gradually relax or give up the control of interest rates, the decision-making rate of interest to the market by the market main body according to the supply and demand situation of funds to determine the process itself, the core of the interest rate formation mechanism of the market, including interest rate decision, Interest rate transmission, interest rate structure and marketization of interest rate management. In the interest rate market conditions, commercial banks will face a huge interest rate risk.

Transitional Risk. Transitional interest rate risk refers to the early stages of interest rate liberalization, commercial banks cannot adapt to changes in market interest rates, resulting in financial risks. Transitional risk arises from the interest rate control to the market transition stage, with a systematic, transitional characteristics, but with the transition phase is completed, the transitional risk will tend to disappear. After the marketization of interest rates, the sharp rise in interest rates and interest rates is the root cause of the transitional risk of commercial banks. According to international experience, the implementation of interest rate market, the real interest rate in China will generally rebound. The formation of greater pressure on the rise in interest rates is the slow reform of Chinese investment system, the state-owned enterprises have not yet rationalized the business behavior, resulting in the irrational demand for funds, resulting in a huge funding gap; the other financial system is also a degree of improvement cannot be ignored factors, Chinese banking market is basically a "oligopoly" of the market, it is easy to manipulate the price of funds. (3) the incentive to compete on the source of funds; (4) the debt burden increased; (5) the increase in the financial burden of the transfer; (2) the increase in the financial burden of the increase; The And long-term survival in the regulatory state of financial institutions often cannot adapt to this change, cannot grasp the law of interest rate changes, and no suitable financial instruments to avoid interest rate risk. So the rise in interest rates and violent volatility are often a direct result of the banking crisis.

Re-Pricing Risk. Re-pricing risk, also known as maturity does not match the risk, is the most 
important commercial banks and the most common interest rate risk. It comes from the time difference between the maturity of the bank's assets, liabilities and off-balance sheet business (in terms of fixed interest rates) and repricing (in terms of floating interest rates). While the asymmetry of such repricing is the basis of the banking business, they will cause the bank's spreads and net worth to change unexpectedly as interest rates change. Banks often refer to the difference between interest rate-sensitive assets and interest-rate-sensitive liabilities over a period of time as a "repricing gap." As long as the gap is not zero, the interest rate changes, the bank will face interest rate risk. In the case of frequent interest rate fluctuations and lack of risk management, banks will face greater risk of re-pricing. At present, Chinese unbalanced balance sheet results in serious risk of re-pricing of commercial banks. From 1996 to 1999, Chinese continuous interest rate reduction, for example, Chinese commercial banks deposits more than one year deposit-based, and loans to a short period of one year short-term loans, reflected in the balance sheet, expressed as Long-term liabilities corresponding to short-term assets, the bank is in a positive state, so the interest rate decreased to reduce the bank's interest income.

Yield Curve Risk. The yield curve is a collection of interest rates at different maturity structures. Under normal circumstances, long-term interest rates should be higher than short-term interest rates, because long-term assets or liabilities than the short-term assets or liabilities with greater uncertainty, facing greater risk, and accordingly should have greater gains. Therefore, under normal circumstances the yield curve is upward tilt, that is, the term structure and interest rate levels are positively correlated. The accidental displacement or slope of the yield curve unexpected changes in the bank deposit and lending rates will be inconsistent, when the yield curve changes to the bank's potential income or value of a negative impact, the risk of income curve. There are two forms of profit curve risk: one is the existence of interest rate fluctuations in the case of inconsistency, the deposit and loan spreads led to the reduction of bank interest income risk; the other is the short-term deposit and lending spreads and long-term deposit In the case of inconsistent volatility, the risk of net interest income is less due to the inconsistency between such inconsistency and the structure of bank assets and liabilities. In general, the yield curve is always upward, that is, long-term interest rates higher than short-term interest rates. But in the business cycle expansion stage, in order to curb investment, the central bank to take reverse monetary policy, short-term interest rates will be higher than the long-term interest rate phenomenon. Short-term interest rates upside down, will make the original bank's expected liabilities and liabilities difference. In the financial panic period, long and short interest rates upside down phenomenon will often appear.

The Basic Point Risk. The basic point of risk is another important interest rate risk faced by banks. When the change in the general interest rate level causes the change of interest rate of different kinds of financial instruments, the bank's profit will face certain risks, that is, the basic point of risk. Even if the bank has the same re-pricing time for assets and liabilities, banks will be at risk as long as the adjustment rate of the deposit rate is not exactly the same as the adjustment of the loan interest rate. Assuming that in a international business, a financial institution absorbs a one-year deposit, which is re-priced once a month in accordance with the London Interbank Offered Rate (LIBOR) and applies the funds to a one-year loan According to the US Treasury bill rate once a month to re-pricing. Since the Treasury bill rate and LIBOR are rarely adjusted by the same rate, the institution faces the risk of a change in net interest margin resulting from unexpected changes in the spreads of the two benchmark rates.

Containing Option Risk. The importance of including the option risk in the interest rate risk of a commercial bank is increasing, and the option gives the holder the right to buy, sell or otherwise change the cash flow of a tool or financial contract in some way. Options can be separate tools, such as floor trading options and OTC options, which are off-balance-sheet business banks, but the option risk here is primarily attributable to the implied in the business of the bank's balance sheet option risk. They include various types of long-term and medium-term bonds with interestable or sellable terms, interest rate marketization and commercial bank interest rate risk control strategies that allow borrowers to repay loans in advance and allow depositors to withdraw money at all times do not charge any fine of all kinds of unlimited tools. If not properly managed, such options will be 
extremely risky for the seller due to their asymmetric payment characteristics, since either direct or implied options are generally beneficial to the buyer when the seller is unfavorable. Moreover, now more and more options varieties with a high leverage effect, which will further expand the options position on the bank's financial situation favorable or adverse effects. Implicit option risk often occurs when the market interest rate changes significantly. If the borrower does not face a fine due to the early repayment of the loan, they will return the bank loan in advance of the interest rate drop and then finance at a low interest rate. Similarly, if the depositor does not face more fines due to advance withdrawals, the rise in market interest rates will prompt depositors to withdraw their time deposits from banks in advance and then re-enter banks at higher rates or invest in other a higher yield tool. As interest rates rise and fall, banks are exposed to a certain degree of risk because they exercise options that are included in deposit and loan contracts.

\section{The Commercial Bank Interest Rate Risk Control Strategy}

Strengthen Asset and Liability Management and Control Interest Rate Risk. Commercial bank management is usually referred to as asset and liability management by changing the balance sheet of the various components and structure, to affect the degree of interest rate exposure, and then change the interest rate sensitivity of the balance sheet. Changes in interest rate sensitivity gaps and duration gaps can be achieved by adjusting the balance sheet. In general, there are two strategies for bank asset-liability management. First, according to the trend of interest rate change, the balance of assets and liabilities is expanded to obtain the benefits in the interest rate change. This is also called the active strategy. The implementation of the active strategy requires the risk. This strategy should first be to predict the interest rate trend, on this basis, and then determine the bank can bear the maximum amount of income reduction and the maximum gap. The other is to maintain the balance between sensitive and sensitive liabilities, as far as possible so that the grade of the debt gap is zero, especially the cumulative gap is zero, regardless of how the interest rate changes, the bank's net interest income or the bank's value does not change, it is also called defense strategy. In implementing the defensive strategy, the interest rate of the assets and liabilities should be divided as much as possible, and the gap in each grade should be as small as possible; secondly, the assets and liabilities with similar nature should be combined as much as possible Properties of similar assets and liabilities, the impact of changes in interest rates are similar.

Active strategies, while gaining gains in interest rate changes, also make banks more risky, and once banks change against the expected change, banks will suffer more losses. After the interest rate is marketed, the change in interest rates is more complex, the uncertainty of interest rates is stronger, and the change in interest rates is difficult to predict. Therefore, the active strategy may make the bank earn a lot of money, but it also brings great risks.

The basic tool for the management of the balance sheet is to buy or sell securities of different maturity periods, and to buy or sell assets or liabilities of different periods in accordance with the degree of interest rate risk borne by the commercial banks to achieve a balance between the balance of assets and liabilities purpose. Banks can calculate the sensitivity gap through the interest rate sensitivity gap model or the duration model, and then reduce the interest rate risk by adjusting the number and duration of assets and liabilities. For example, by calculating that the balance sheet is a positive gap, that is, sensitive assets are greater than the sensitive liabilities and we can adjust the balance sheet in the portfolio, sell short-term bonds, buy long-term fixed-rate bonds, and reduce interest-rate sensitive assets. By buying and selling bonds of different maturity, you can significantly reduce the bank interest rate risk exposure in the short term. Specifically, if the balance of assets is a positive gap, the following methods can be used to reduce the interest rate sensitivity gap: to extend the duration of the portfolio, increase short-term deposits, increase fixed-rate loans, increase short-term loans, If the balance of assets is a negative gap, the following methods can be used to reduce interest rate sensitivity gap: shorten the duration of the portfolio, increase long-term deposits, reduce fixed-rate bonds, increase fixed-rate long-term debt, increase floating rate loans.

Use Financial Innovation Tools to Control Interest Rate Risk. At present, there are many innovative financial instruments in interest rate risk management in western commercial banks, 
such as interest rate futures, interest rate options, interest rate swaps and interest rate forward contracts, interest rate agreements, etc., using financial derivatives hedging, can greatly enhance The flexibility of interest rate risk management. Commercial banks do not have to pay too much attention to whether the market has the opportunity to obtain the required assets, nor do they have to give up a favorable investment opportunity because of the matching of assets and liabilities, as long as the derivatives market can be easily operated. Although China has no financial derivatives market can be transferred for commercial banks, decentralized interest rate risk, and even gain, but many banks have used financial derivatives in domestic and foreign markets to avoid interest rate risk. With the advancement of Chinese market economy and the international economy, the derivatives market will have a big development. According to the current development of Chinese current situation, I think that China should give priority to the development of national debt futures market, because: First, after years of development, China already has a huge treasury bond market, the issue of large quantities of the bond repurchase market has basically achieved market.

\section{Conclusion}

The steady progress of the interest rate marketization process will have a significant impact on the living environment and management of Chinese commercial banks. How to deal with the market situation of interest rate market and raise the level of interest rate risk control in the increasingly market-oriented and increasingly open business environment in an invincible position, it is an urgent task for commercial banks to respond positively.

\section{References}

[1] Han Bing, Yang Jun. Commercial banks to strengthen the management of interest rate risk [J]. China Finance. 2003 (16)

[2] Interest rate risk management of commercial banks [J]. China Urban Finance. 2003 (07)

[3] Miao Yunduo. Actively deal with the market-oriented reform of interest rates to establish commercial banks deposit and loan pricing mechanism [J]. China Finance. 2003 (13)

[4] Henan Province Urban Finance Institute task group in the interest rate market conditions to build commercial banks interest rate risk prevention mechanism [J]. Finance Forum. 2003 (06)

[5] Shen Shisheng. Take the initiative to meet the challenges of marketization of foreign currency interest rates [J]. China Foreign Exchange Administration. 2000 (12)

[6] Ba Jusong. Chinese interest rate market reform is ready to come out [J]. International Finance Research. 2000 (01) 